\title{
Membangun Nilai-Nilai Etika Melalui Budaya Lokal Banten Sebagai Upaya Pencegahan Kasus Tindak Pidana Korupsi di Provinsi Banten
}

\author{
Usmaedi $^{*}$, Ade Eka Anggraini ${ }^{2}$, Suherman ${ }^{3}$, Eka Nurul Mualimah ${ }^{4}$, Elih Solihatulmilah ${ }^{5}$ \\ 1,4,5STKIP Setiabudhi, ${ }^{2}$ Universitas Negeri Malang, ${ }^{3}$ Universitas Sultan Ageng Tirtayasa \\ *usmaedikentlee@gmail.com
}

\begin{abstract}
This study examines the criminal act of corruption in Banten. Corruption must be seen as a necessary extra ordinary crime because it also requires extraordinary efforts to eradicate it. The corruption case in Banten is very worrying because it is the head of the region (governors, regents and officials in the Banten province) who commit corruption. Districts that require special attention are Serang Regency, Lebak Regency and Pandeglang Regency. The research method used is a qualitative method. The data study technique through literature review was carried out by document study. Literature review is the analysis, evaluation and synthesis of knowledge that is relevant to the problem to be conveyed. The people of Banten are famous for their religiosity values, and have the nature of championship or kebantenan in running the government with a dynastic system, which is carried out by the children, grandchildren, and son-in-law of a regent. Banten, which has abundant natural resources, is very unfortunate for the behavior of many officials who commit criminal acts of corruption, so that the potential of Banten Province, which is the gateway to the island of Java, is not utilized by all Banten people. The inculcation of these values to the people of Banten is carried out in various ways according to their needs. Anti-corruption education for the people of Banten can be provided in various forms, including socialization activities, campaigns or other forms of extracurricular activities. Efforts to improve the system, among others, can be done by improving proper regulations, improving governance, reforming the bureaucracy, creating an anti-corruption work environment, applying the principles of clean governance and good governance, applying technology to transparency and others.

Keywords: ethical values; banten local culture; corruption crime
\end{abstract}

\section{ABSTRAK}

Penelitian ini mengkaji bagaimaana nilai-nilai etika melalui budaya lokal banten dapat pencegah tindak pidana korupsi di Banten. Korupsi harus dipandang sebagai kejahatan luar biasa (extra ordinary crime) yang oleh karena itu memerlukan upaya luar biasa pula untuk memberantasnya. Kasus korupsi di Banten sangatlah menghawatirkan karena yang melakukan korupsi adalah kepala daerah (Gubernur, Bupati dan para pejabat dilingkungan Provinsi Banten). Kabupaten yang memerlukan perhatian khusus adalah Kabupaten Serang, Kabupaten Lebak dan Kabupaten Pandeglang. Metode penelitian yang digunakan adalah metode kualitatif. Teknik pengumpulan data melalui kajian literatur dilakukan dengan studi dokumen. Kajian literatur adalah analisis, evaluasi kritis dan sintesis pengetahuan yang relevan dengan masalah yang ingin disampaikan. Masyarakat Banten yang terkenal dengan nilai relegiusitasnya, dan mempunyai sifat kejawaraan atau kebantenan di dalam menjalankan pemerintahan dengan sistem dinasti artinya pemerintahan yang dijalankan akan dilanjutkan oleh anak, cucu, menantu dari seorang Bupati. Banten yang memiliki sumberdaya alam yang sangat melimpah sangat disayangkan jika prilaku para pejabat banyak yang melakukan tindak pidana korupsi, sehingga potensi sebagai Provinsi Banten yang merupakan pintu gerbang ke pulau Jawa tidak dimanfaatkan oleh seluruh masyarakat Banten. Penanaman nilai-nilai ini kepada masyarakat Banten dilakukan dengan berbagai cara yang disesuaikan dengan kebutuhan. Pendidikan anti- korupsi bagi masyarakat Banten dapat diberikan dalam berbagai bentuk, antara lain kegiatan sosialisasi, seminar, kampanye atau bentuk-bentuk kegiatan ekstra kurikuler lainnya. Upaya perbaikan sistem antara lain dapat dilakukan dengan memperbaiki peraturan perundang-undangan yang berlaku, memperbaiki tata kelola pemerintahan, reformasi birokrasi, menciptakan lingkungan kerja yang anti-korupsi, menerapkan prinsip-prinsip clean and good governance, pemanfaatan teknologi untuk transparansi dan lain-lain.

Kata Kunci: nilai-nilai etika; budaya lokal banten; tindak pidana korupsi. 


\section{Pendahuluan}

Pada hakekatnya manusia adalah individu yang berbudi dan berkehendak. Kepribadian berarti dasar keseluruhan dan kesatuan tindakan manusia yang berbudi dan berkehendak itu. Manusia yang berkepribadian etis ialah manusia yang dalam tindakannya selalu memilih yang baik sesuai dengan penerangan budinya (Sumantri, 2011; Wulandari, 2012; Nurhayati, 2019).

Provinsi Banten adalah sebuah provinsi, wilayah paling barat di Pulau Jawa, Indonesia. Provinsi ini pernah menjadi bagian dari Provinsi Jawa Barat, daerah ini menjadi wilayah pemekaran sejak tahun 2000, dengan keputusan Undang-Undang Nomor 23 Tahun 2000. Pusat pemerintahannya berada di Kota Serang. Provinsi Banten menyuguhkan peluang investasi, mulai dari sektor pertanian hingga pariwisata. Peluang investasi di sejumlah kabupaten di Banten. Sebagai daerah yang meliliki potensi sumber daya alam yang sangat banyak membuat Provinsi Banten banyak didatangi oleh investor asing. Investasi yang datang ke Banten membuat pemerintah daerah dan para pengusaha membuat kebijakan yang tidak pro terhadap masyarakat Banten, dimana banyaknya pelanggaran yang dibuat oleh oknum dari pemerintah Banten dan pengusaha agar investasi sesuai dengan yang mereka inginkan dengan mendapatkan keuntungan yang sebanyak-banyaknya tanpa memperdulikan lingkungan perekonomian dan dampak lingkungan sehingga praktek korupsi terjadi dengan sengaja ataupun tidak disengaja oleh oknum pemerintah Banten dan para pengusaha.

Tindak pidana korupsi salah satu penyebab sistem perekonomian bangsa menurun sangat pesat, karena korupsi di Indonesia terjadi secara meluas sehingga merugikan perekonomian negara atau kondisi keuangan negara. Perlu penanggulangan tindak pidana korupsi dengan cara yang sangat luar biasa dan perlu menciptakan cara-cara yang khusus. Korupsi sebagai perbuatan yang dilakukan dengan maksud untuk memberikan suatu keuntungan yang tidak resmi dengan hak-hak dari pihak lain secara salah, menggunakan jabatannya atau karakternya untuk mendapatkan suatu keuntungan untuk dirinya sendiri atau orang lain, berlawanan dengan kewajibannya dan hak-hak dari pihak-pihak lain (Syamsuddin, 2011; Ridwan, 2012).

Korupsi dari bahasa latin corruption, dari kata kerja corrumpere yang berarti busuk, rusak, menggoyahkan, memutar balik, menyogok. Korupsi adalah perilaku pejabat publik, baik politis maupun pegawai negeri, yang secara tidak wajar dan tidak legal memperkaya diri atau memperkaya mereka yang dekat dengannya, dengan menyalahgunakan kepercayaan publik yang dikuasakan kepada mereka untuk mendapatkan keuntungan sepihak. Secara harfiah kata korupsi menunjuk pada perbuatan yang rusak, busuk, tidak jujur yang dikaitkan dengan keuangan (Parapat, 2020).

Korupsi merupakan penyogokan, penyuapan, penggelapan, perbuatan yang buruk atau sering disebut suka menerima uang sogok, penyalahgunaan jabatan/wewenang untuk kepentingan diri sendiri, melakukan suatu tindakan pidana dengan maksud memperkaya diri sendiri secara langsung maupun tidak langsung dimana perbuatan itu merugikan keuangan negara dan perekonomian dalam Negara (Sholihin, \& Yulianingsih, 2015). Korupsi adalah suatu perbuatan anti sosial yang sering dikenal sebagai belahan dunia, namun beberapa orang mengartikan bahwa korupsi bukan suatu bentuk kejahatan yang baru dan kejahatan ini hanya berkembang di indonesia ini.

Dengan adanya predikat bahwa tindak pidana korupsi merupakan kejahatan luar biasa (Extraordinary Crime), maka harus ada peraturan atau undang-undang khusus yang mengatur mengenai tindak pidana korupsi. Tindak Pidana Korupsi diatur lebih khusus pada Undang-Undang No. 20 tahun 2001 tentang perubahan atas Undang-Undang No. 31 tahun 1999 tentang Pemberantasan Tindak Pidana Korupsi. Adanya Undang-Undang No. 20 tahun 2001, maka dalam pemberantasan tindak pidana korupsi digunakan asas hukum yaitu "lex specialis derogat legi generali", yaitu asas penafsiran hukum yang menyatakan bahwa hukum yang bersifat khusus (lex specialis) mengesampingkan hukum yang bersifat umum (lex generalis) (Wikipedia, n.d.) .

Upaya yang dapat dilakukan adalah dengan membentuk suatu peradilan khusus untuk Tindak Pidana Korupsi sebagaimana disebutkan dalam UndangUndang No.46 Tahun 2009 pasal 2 
menyebutkan bahwa Pengadilan Tindak Pidana Korupsi merupakan pengadilan khusus yang berada di lingkungan Peradilan Umum. Dalam hal ini Pengadilan Tindak Pidana Korupsi merupakan satusatunya pengadilan yang berwenang memeriksa, mengadili, dan memutus perkara tindak pidana korupsi (Undang-Undang Nomor 46, 2009). Peraktik-praktik mafia paling sering menggerogoti sendi-sendi kriminal atau sistem pengadilan pidana di Indonesia ini dimulai sejak proses penyelidikan, penuntutan, pemutusan eksekusi dan pemasyarakat (Hartanti, 2009).

Pemberantasan tindak pidana korupsi adalah serangkaian tindakan untuk mencegah dan memberantas tindak pidana korupsi melalui upaya koordinasi, supervisi, monitor, penyelidikan, penyidikan, penuntutan, dan pemeriksaan di sidang pengadilan, dengan peran serta masyarakat berdasarkan peraturan perundang-undangan yang berlaku ("UU Nomor 30 Tahun 2002," n.d.). Karenanya ada tiga hal yang perlu digarisbawahi yaitu 'mencegah', 'memberantas' dalam arti menindak pelaku korupsi, dan 'peran serta masyarakat'.

Korupsi yang terjadi di Indonesia sudah bersifat kolosal dan ibarat penyakit sudah sulit untuk disembuhkan. Korupsi dalam berbagai tingkatan sudah terjadi pada hampir seluruh sendi kehidupan dan dilakukan oleh hampir semua golongan masyarakat. Dengan kata lain korupsi sudah menjadi bagian dari kehidupan kita sehari-hari yang sudah dianggap biasa. Oleh karena itu, sebagian masyarakat menganggap korupsi bukan lagi merupakan kejahatan besar. Jika kondisi ini tetap dibiarkan seperti itu, maka hampir dapat dipastikan cepat atau lambat korupsi akan menghancurkan negeri ini. Oleh karena itu, sudah semestinya kita menempatkan korupsi sebagai musuh bersama (common enemy) yang harus kita perangi bersama-sama dengan sungguh-sungguh. Karena sifatnya yang sangat luar biasa, maka untuk memerangi atau memberantas korupsi diperlukan upaya yang luar biasa pula.

Upaya memberantas korupsi sama sekali bukanlah suatu pekerjaan yang mudah dan tidak bisa hanya menjadi tanggung jawab institusi penegak hukum atau pemerintah saja, tetapi juga merupakan tanggung jawab bersama seluruh komponen bangsa. Oleh karena itu, upaya memberantas korupsi harus melibatkan seluruh pemangku kepentingan (stakeholders) yang terkait, yaitu pemerintah, swasta dan masyarakat.

Kasus korupsi di Banten sangatlah menghawatirkan karena yang melakukan korupsi adalah kepala daerah (Gubernur, Bupati dan para pejabat dilingkungan Provinsi Banten). Provinsi Banten berdiri tahun 2000 setelah melepaskan diri dari Provinsi Jawa Barat, sebagai provinsi yang baru pembangunan di seluruh wilayah Banten harus bekerja keras karena yang sudah maju sebagai sebuah Kota adalah Kota Tangerang yang berdekatan dengan daerah DKI Jakarta. Kabupaten yang memerlukan perhatian khusus adalah Kabupaten Serang, Kabupaten Lebak dan Kabupaten Pandeglang.

Korupsi yang terjadi karena sistem pemerintahan yang dijalankan menggunakan politik dinasti dimana sebuah kekuasaan daerah akan dilanjutkan oleh trah dari dinasti bupati baik pemerintahannya dilanjutkan oleh istri, anak, menantu, kerabat dll, sehingga pemerintahan tidak berjalan optimal karena sebuah pemerintahan diatur oleh seorang Gubernur yang mengatur siapa Bupati yang akan menjabat di kabupaten tersebut, proyek pembangunan dikuasai oleh keluarga Gubernur dll, sehingga pembangunan yang ada di Provinsi Banten tidak berjalan bahkan masyarakat tidak mendapatkan pembangunan yang layak baik pendidikan, ekonomi, politik, sosial budaya. Karena sistem pemerintahan diatur oleh kepala daerah dan tidak adanya keberanian dari masyarakat akan ketidakbenaran dalam pengelolaan sistem pemerintahan di Provinsi Banten.

Kasus korupsi di Banten dilakukan oleh Gubernur pertama Djoko Munandar dengan kasus korupsi penyelewengan dana bencana alam sebesar $14 \mathrm{M}$, kasus ke dua dilakukan oleh Gubernur ke dua Ratu Atut Chosiyah dengan melakukan penyuapan kasus pilkada Kabupaten Lebak dengan memberikan uang Rp 1 miliar kepada Ketua MK Akil Mochtar melalui advokat Susi Tur Andayani. Uang itu diberikan untuk memenangkan gugatan yang diajukan pasangan Amir Hamzah dan Kasmin dalam sengketa Pilkada Lebak tahun 2013, kasus korupsi Alkes Tangsel yang dilakukan oleh adik dari 
Gubernur Banten, dengan melibatkan adiknya untuk mengatur penggandaan alkes agar mendapatkan keuntungan yang sebesar-besarnya untuk kepentingan keluarga dinasti Atut (Ardito Ramadhan, 2021). Korupsi yang terjadi di Banten menunjukan betapa para pejabat daerah tidak memberikan contoh yang baik untuk masyarakat dan pembangunan di Banten yang terhabat karena ulah dari pejabat yang korup dan penghancurkan sistem demokrasi dimana dinasti ini berjalan dengan terstruktur, sistematis dan massif (TSM), sehingga wajar Provinsi Banten masih jauh tertinggal dari Provinsi lainnya padahal Banten merupakan pintu gerbang investasi menuju kawasan perekonomian di DKI Jakarta.

Korupsi mempunyai dampak yang sangat luas dalam proses penyelenggara dan pembangunan masyarakat korupsi dikategorikan sebagai extra ordinary crime, yang artinya bahwa korupsi mempunyai masalah lokal, fenomena nasional sangat mempengaruhi masyarakat dan ekonomi hal ini penting melakukan kerja sama antar internasional agar mencegah terjadinya korupsi, maka pendekatan komprehensif diperlukan saat ini untuk mencegah pemberantasan korupsi yang secara efektif (Ali, 1998). Pembentukan suatu aturan hukum dapat menentukan perbuatan yang harus dicegah didalam masyarakat.

\section{Metode Penelitian}

Dalam suatu penelitian sangat dibutuhkan sebuah metode yang berguna untuk memperoleh hasil penelitian yang lebih baik dengan harapan agar hasil penelitiannya bisa lebih objektif lagi. Metode penelitian yang digunakan adalah metode kualitatif (Moleong, 2009). Teknik pengumpulan data melalui kajian literatur dilakukan dengan studi dokumen. Kajian literatur adalah analisis, evaluasi kritis dan sintesis pengetahuan yang relevan dengan masalah yang ingin disampaikan (Hart, 2018). Sementara itu, (Roselle, 2012) menjelaskan tinjauan pustaka sebagai proses membaca dan mengulas penelitian yang telah dipublikasikan sebelumnya. Ketika membicarakan tentang melakukan literature review, maka terfokus pada mengulas literatur-literatur para ahli. Di sisi lain, ketika membahas terkait dengan writing literature review, maka mengacu pada aktivitas menulis sebuah rangkuman dari penelitian tertentu. Ada pun (Bahry, 1995) dalam tulisannya yang berjudul "Setting the Foundation: Techiques of Systematic Bibliograpical Seach" menyatakan bahwa tinjauan pustaka dapat dijelaskan sebagai cara untuk mempelajari hasil penelitian yang telah diterbitkan oleh peneliti sebelumnya untuk mendukung penelitian yang sedang dilakukan. Proses pembelajaran tersebut berkaitan dengan interpretasi dari peneliti yang sedang menjalankan kegiatan penelitian.

Kajian literatur merupakan upaya peneliti mengembangkan penelitian dengan mengulas literatur-literatur sebelumnya. Literatur dapat berupa scholarly book, edited book, hingga artikel jurnal dan buku online. Untuk mengulas literatur-literatur tersebut, peneliti harus terlebih dahulu melakukan empat aktivitas penting yakni mencari berbagai literatur yang sesuai dengan topik penelitian melalui online maupun off-line, mendokumentasikan literatur-literatur tersebut dengan menggunakan komputer maupun cara manual, menentukan literatur-literatur mana yang akan dijadikan sebagai acuan dalam tinjauan pustaka penelitian, serta membaca satu per satu literatur diikuti dengan menjawab pertanyaan fundamental, seperti apa rumusan masalah yang diangkat dalam literatur tersebut, apa variabel dependen dan independen dalam literatur tersebut, bagaimana kesimpulan yang dipaparkan peneliti mengenai keterkaitan antara variabel dependen dan independen dalam literatur tersebut, serta apa kelebihan dan kelemahan literatur tersebut.

\section{Hasil dan Pembahasan}

Upaya Pencegahan tindak pidana korupsi pada dasarnya adalah upaya bersama seluruh komponen bangsa untuk mencegah peluang terjadinya perilaku koruptif. Dengan kata lain gerakan antikorupsi adalah suatu gerakan yang memperbaiki perilaku individu (manusia) dan sistem untuk mencegah terjadinya perilaku koruptif. Diyakini bahwa upaya perbaikan sistem (sistem hukum dan 
kelembagaan serta norma) dan perbaikan perilaku manusia (moral dan kesejahteraan) dapat menghilangkan, atau setidaknya memperkecil peluang bagi berkembangnya korupsi di Banten.

Masyarakat Banten yang terkenal dengan nilai relegiusitasnya, dan mempunyai sifat kejawaraan atau kebantenan di dalam menjalankan pemerintahan dengan sistem dinasti artinya pemerintahan yang dijalankan akan dilanjutkan oleh anak, cucu, menantu dari seorang Bupati. Banten yang memiliki sumberdaya alam yang sangat melimpah sangat disayangkan jika prilaku para pejabat banyak yang melakukan tindak pidana korupsi, sehingga potensi sebagai Provinsi Banten yang merupakan pintu gerbang ke pulau Jawa tidak dimanfaatkan oleh seluruh masyarakat Banten.

Kebanyakan orang merasa bahwa norma-norma dan hukum-hukum mempunyai peranan yang besar dalam bidang etika (Malcolm Brownlee, 1991). Upaya perbaikan perilaku manusia antara lain dapat dimulai dengan menanamkan nilai-nilai yang mendukung terciptanya perilaku antikoruptif. Nilainilai yang dimaksud antara lain adalah kejujuran, kepedulian, kemandirian, kedisiplinan, tanggung jawab, kerja keras, kesederhanaan, keberanian, dan keadilan. Penanaman nilai-nilai ini kepada masyarakat Banten dilakukan dengan berbagai cara yang disesuaikan dengan kebutuhan. Pendidikan anti- korupsi bagi masyarakat Banten dapat diberikan dalam berbagai bentuk, antara lain kegiatan sosialisasi, seminar, kampanye atau bentuk-bentuk kegiatan ekstra kurikuler lainnya. Upaya perbaikan sistem antara lain dapat dilakukan dengan memperbaiki peraturan perundang-undangan yang berlaku, memperbaiki tata kelola pemerintahan, reformasi birokrasi, menciptakan lingkungan kerja yang antikorupsi, menerapkan prinsip-prinsip clean and good governance, pemanfaatan teknologi untuk transparansi dan lain-lain. Tentu saja upaya perbaikan sistem ini tidak hanya merupakan tanggung jawab pemerintah saja, tetapi juga harus didukung oleh seluruh pemangku kepentingan termasuk masyarakat.

Matinya Etika Sosial Politik Korupsi bukan suatu bentuk tindak pidana biasa karena ia merusak sendi-sendi kehidupan yang paling dasar yaitu etika sosial bahkan kemanusiaan. Kejujuran sudah tidak ditegakkan lagi dan yang paradoksal adalah siapa pun yang meneriakkan kejujuran justru akan diberikan sanksi sosial dan politik oleh otoritas menteri, aparat penguasa bahkan oleh masyarakat sendiri. Kejujuran yang dihadapi dengan kekuatan politik adalah sesuatu yang tidak mendidik dan justru bertentangan dengan etika dan moralitas. Pada saat ini kekuatan politik sangat dominan, sehingga suatu kelompok politik akan rela melindungi anggotanya dengan segala cara, meskipun anggotanya tersebut jelas-jelas bersalah atau melakukan korupsi. Hal ini sangat melukai nurani masyarakat, padahal mereka adakah wakil rakyat yang seharusnya melindungi kepentingan rakyat. Melindungi seorang koruptor dengan kekuatan politik adalah salah satu indikasi besar runtuhnya etika sosial dan politik.

Nilai-nilai masyarakat Banten yang religius, jujur seharusnya dapat menaggulangi segala bentuk tindak kejahatan (korupsi) karena dengan mengimplementasikan nilai religius seseorang dapat digoyangkan prinsip dari adanya tindakan korupsi karena seseorang akan takut jika melakukan tindakan korupsi akan mempertanggung jawabkan kepada sang maha pencipta.

Reformasi birokrasi merupakan salah satu upaya pemerintah provinsi Banten untuk mencapai good governance dan melakukan pembaharuan dan perubahan mendasar terhadap sistem penyelenggaraan pemerintahan daerah terutama menyangkut aspek-aspek kelembagaan (organisasi), ketatalaksanaan dan sumber daya manusia aparatur. Melalui reformasi birokrasi, dilakukan penataan terhadap sistem penyelenggaraan pemerintah daerah di mana uang tidak hanya efektif dan efisien, tetapi juga reformasi birokrasi menjadi tulang punggung dalam perubahan kehidupan berbangsa dan bernegara. Tujuan reformasi birokrasi adalah untuk menciptakan birokrasi pemerintah yang profesional dengan karakteristik, berintegrasi, berkinerja tinggi, bebas dan bersih KKN, mampu melayani publik, netral, sejahtera, berdedikasi, dan memegang teguh nilai-nilai dasar dan kode etik aparatur negara.

\section{Kesimpulan}

Membudayakan gerakan anti korupsi, adalah upaya yang sungguh - sungguh dan berkelanjutan dari pemerintah dengan menanamkan pemahaman bahwa korupsi adalah perbuatan yang tercela 
berdasarkan agama, sosial dan hukum. Gerakan anti korupsi, akan menimbulkan budaya malu melakukan korupsi, dan sikap anti terhadap perbuatan-perbuatan korupsi dalam masyarakat sehingga akan melaporkan kepada aparat penegak hukum, dan mengawasi prosesnya.

\section{Daftar Pustaka}

Ali, M. (1998). Teori Dan Praktek Hukum Pidana Korupsi. Yogyakarta.

Ardito Ramadhan. (2021). Kasus Suap Akil Mochtar, Mantan Gubernur Banten Ratu Atut Chosiyah Ajukan PK. Retrieved from https://nasional.kompas.com/read/2021/01/06/16103761/kasussuap-akil-mochtar-mantan-gubernur-banten-ratu-atut-chosiyah-ajukan-pk

Bahry, D. L. (1995). Setting the Foundation: Technique of System Bibliographic Research. London: Longman Publisher.

Hart, C. (2018). Doing a Literature Review: Releasing the Research Imagination. SAGE Publication.

Hartanti, E. (2009). Tindak pidana korupsi edisi kedua. Jakarta: Sinar Erlangga.

Malcolm Brownlee. (1991). Pengambilan Keputusan Etis. Jakarta: Gunung Mulia.

Moleong, L. (2009). Metode Penelitian Kualitatif. Bandung: PT Remaja Rosdakarya.

Nurchayati, Z. (2019). Penguatan Etika Dalam Berkomunikasi Pada Remaja Di Kabupaten Madiun. Jurnal Daya-mas, 4(1).

Parapat, Y. T. W. M. (2020). Upaya Penanggulangan Tindak Pidana Korupsi Pada Masa Pandemi Covid-19. Esensi Hukum, 2(2), 23-35.

Ridwan, R. (2012). Kebijakan Formulasi Hukum Pidana Dalam Penanggulangan Tindak Pidana Korupsi. Law Reform, 8(1), 78-98.

Roselle, L. dan S. S. (2012). Scholarly Literature and The Literature Review. New York: Pearson Longman.

Sholihin,F. dan Yulianingsih, W. (2015). Kamus Hukum Kontemporer. Surabaya: Sinar Grafika.

Sumantri, E. (2011). Pendidikan Karakter: Nilai Inti Bagi Upaya Pembinaan Kepribadian Bangsa. Bandung: Widya Aksara Press.

Syamsuddin, A. (2011). Tindak. Pidana Khusus. Jakarta: Sinar Grafika.

Undang-Undang Nomor 46. (2009). Pengadilan Tindak Pidana Korupsi.

UU Nomor 30 Tahun 2002. (n.d.).

Wikipedia. (n.d.). Lex Specialis Derogat Legi General.

Wulandari, A. P. J. (2012). Gambaran Kejujuran sebagai Landasan Keutamaan Moral Mahasiswa yang sudah Pernah Mengambil Mata Kuliah Character Building. Humaniora, 3(2), 566-572. 